\title{
朝鮮通信使による風景の記述に見られる風景生成と 定着について
}

\author{
Landscape Generation and Establishment of Landscape Expression by Korean Envoys Diplomatic \\ Missions
}

西嶋啓一郎* 仲間浩一**

Keiichiro NISHIJIMA Koichi NAKAMA

摘要 : 景観研究にとって, 特定の意味づけが風景イメージとして実景に投影される過程を明らかにす ることは，風景生成の内容を理解する鍵になる。本論では，歴代の通信使の紀行文と漢詩集をテキス トにし, 瀬戸内海鞆浦での風景生成を考察した。その結果, 通信使の風景記述方法には, 次のパター ン化された図式が確認された。通信使は, 過去の通信使の風景記述を受け継き, 洞庭湖や潇湘八景の 風景イメージを実景に投影するため，鞆浦の空間の実体的な要件を確認した。そして，その認識によ り主体の内面に特定の意味づけが行われた結果,「日東第一形勝」という風景が生成された。このこ とにより, 通信使による䩡浦での風景の生成と定着が明らかになった。

\section{1. 研究の目的と位置付け}

風景を構成する様々な要素は, ある特定の意味之結び付けて認 識されることがある。また, 特定の社会集団あるいは特定の文化 圈内で暮らしている人々のあいだで, ある種の風景イメージが共 有されている場合, そのイメージは, 実景に投影される性質があ る。景観研究にとって, 特定の意味づけが風景イメージとして実 景に投影される過程を明らかにすることは, 風景生成の内容を理 解する鍵となる。

1607 年から 1811 年までの 12 回にわたって来日した朝鮮通信 使は, 経路瀬戸内海鞆浦において, 福禅寺対潮楼加ら見る瀬戸内 海の風景を日本で一番だと評価した。その際に意味づけられた風 景イメージは, 鞆浦の風景を, 中国洞庭湖の風景や潚湘八景に見 立てたあのであった。そして, この風景生成は, 朝鮮通信使が幾 代にもわたり定着させてきた評価が下敷きになって行われた。朝 鮮通信使の瀬戸内海における風景評価には, 西田による研究があ り, その図式となっているのが中国の潚湘八景であることを文献 調查により例証している ${ }^{11}$ 。また, 第 9 次通信使（1719）におけ
る申維翰の『海游録』について, 風景記述を分析した先行研究て は，通信使の風景生成には段階的な発展があり，鞆浦において 「神仙境」の意味づけが確信されたことにより風景生成に至った ことが確認されている2゙。

本論では, これらの先行研究の認識を踏まえ, 第 1 次回答兼刷 還使 (1607) における副使慶七松の『海槎録』 ${ }^{3)}$, 第 6 次通信使 （1655）における従事官南龍翼の『扶桑録』，第 7 次通信使 （1682）に抢ける訳官金指南の『東檥日録』，同訳官洪禹載の『東 槎』第 8 次通信使 (1711) における副使任守幹の『東槎日記』7 , 第 9 次通信使 (1719) における製述官申維翰の『海游録』 ${ }^{8)}$, 第 10 次通信使 (1748) における従事官曹命采の『奉使日本時聞見録』9? 第 11 次通信使 (1764) における正使趙嚴の『海榚日記』是, 福禅 寺に残された通信使の漢詩をま之めた『朝鮮通信使漢詩集』等 の現在日本で入手可能な翻訳文献をテキストにし，これらにあら わされた風景評価の意味づけの過程と内容を，年代を扔って考察 することにより, 朝鮮通信使による風景の記述を介して, 生成さ れた風景を共有し定着させた経緯を明らかにすることを研究の目

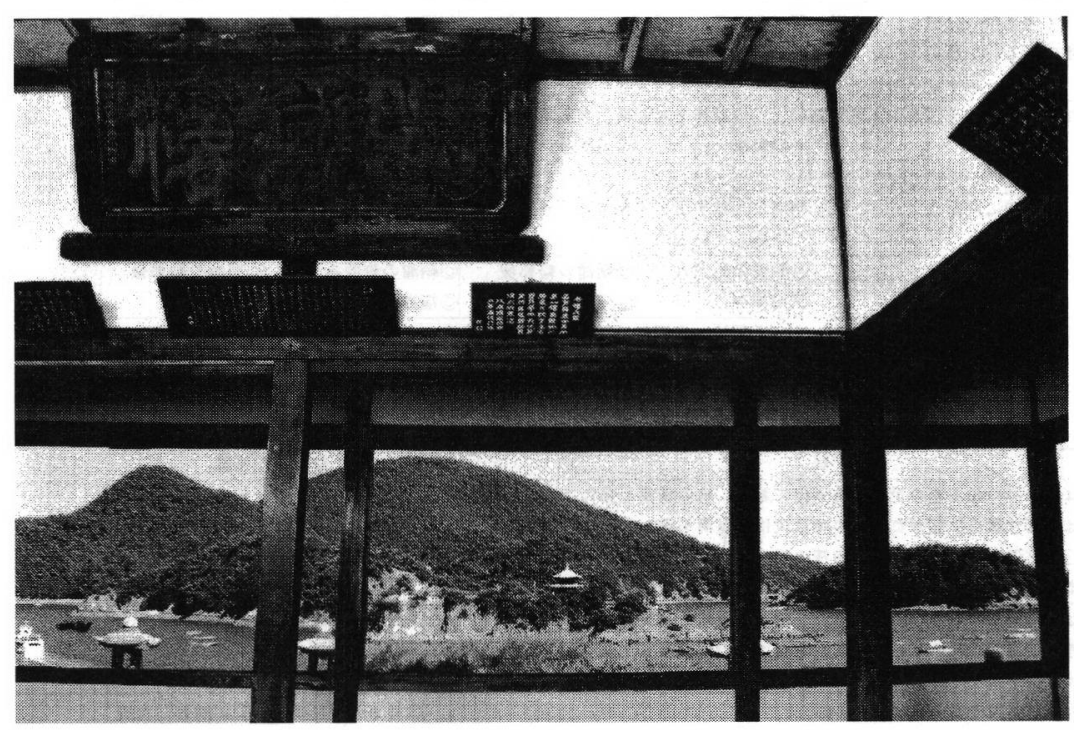

図-1＼cjkstart福禅寺対潮楼からの瀬戸内海の風景

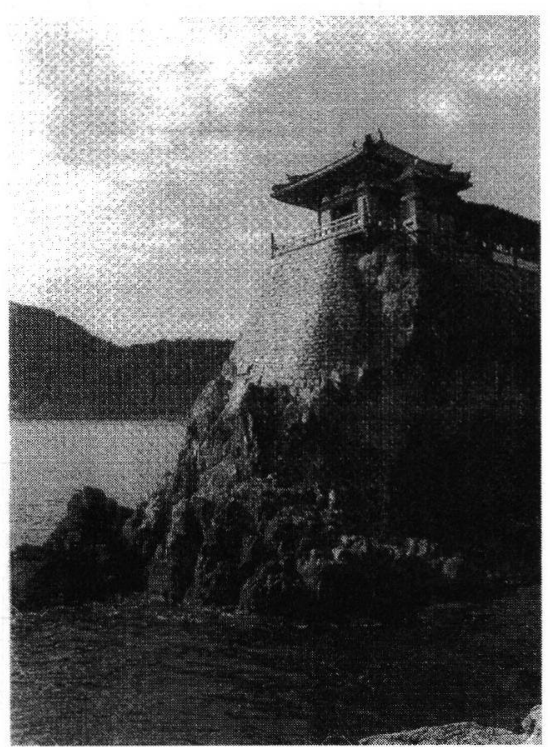

図－２海潮山磐台寺

"九州工業大学大学院工学研究科 **九州工業大学工学部建設社会工学科 
的とする。

\section{2. 研究の方法}

(1) 分析の方法

本論では, 朝鮮通信使一行の経路の中で, 瀬戸内海鞆浦で行わ れた風景の生成を研究対象にする。歴代の通信使一行は, 来日し た際には，必ず訪日録の紀行文を編纂し，また書や絵を館舎となっ た福禅寺等に残している。風景について, 通信使が特に執着した のが福禅寺対潮楼から眺めた瀬戸内海の風景であった（図－1参 照)。通信使一行は，過去の記録を読み，過去の通信使たちが賞 賛した風景を確認し, さらに賞賛した。その内容は, 鞆浦を岳陽 に，海潮山磐台寺や福禅寺を岳陽楼に，そして瀬戸内海を洞庭湖 に意味づけをし，体験する風景を潇湘八景に結び付けて鑑賞する あのであった。しかしこの場合，通信使一行は，中国内陸部の洞 庭湖には実際に訪れたことは恐らくなく, 漢詩や山水画などから 得た渺湘八景の風景イメージが，風景を見つめる主体の内面に意 味づけられていたと推察できる。そこで 3 章では, まず, 歴代通 信使が鞆浦で風景生成を行っている記述をテキストから引用し, 時代ごとにそれぞれの時点で, 主体が対象景と対峙する状況や風 景生成の内容を整理する。4 章では, 過去の通信使によって記述 された鞆浦の風景が, 次の通信使に受け継がれ定着する経緯につ いて, それぞれの時代での風景評価の定着経緯をフローチャート にまとめる。そして, その流れから解明できる鞆浦での風景生成 における意味づけの図式を考察する。

（2）潇湘八景について

洞庭湖は，中国湖南省北部長江南岸にある中国第二の淡水湖で ある。湖周辺の土地は, 平原が広く, 土地は肥沃で, 気候は温暖 湿潤である。湖南省の東北部に位置する岳陽 ${ }^{12)}$ は, 洞庭湖と長江 の合流点にあり, 岳陽楼 ${ }^{(3)}$ は, 岳陽古城西門の上に構築され, 眼 下に洞庭湖, 北に長江を望む高さ $20.35 \mathrm{~m}$ の木造建築の楼閣であ
る。岳陽の西南, 洞庭湖の中の東北には, 君山神) が島として位置 する。君山は中国固有の山岳信仰 ${ }^{15)}$ の山で, 山上には, 二妃墓 ${ }^{16)}$ や始皇帝封山印 ${ }^{17)}$ などがある。『拾遺記』には「洞庭山水上に浮 かび，其の下に金堂数百間有り，玉女之に居り，四時に金石系竹 の音を聞き, 山頂に徹す」と記され ${ }^{18)}$, 洞庭湖の下には, 神仙境 があることを伝えている。

岳陽楼から望む洞庭湖の風景は, 古くから漢詩や山水画にあら わされた。宋代には，洞庭湖から注ぐ潚水と湘水の風水の中から， 「平沙落雁」「遠浦帰帆」「山市青嵐」「江天暮雪」「洞庭秋月」「潇 湘夜雨」「煙寺晚鐘」「漁村夕照」の八佳景が定められ, 潚湘八景 の風景評価が定着した。これは，北宋の宋迪 ${ }^{19)}$ が嘉祐年間

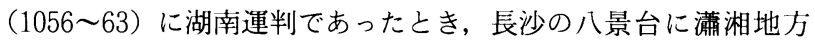
の煙霞に包まれた山水風景を描き, 後, 僧の慧洪がこれに詩を賦 したのがはじまりといわれている20)。

朝鮮通信使によって生成された風景は, これら洞庭湖の風景や 潇湘八景のイメージが下敷きになっており, 西田による研究でも 指摘されているところである ${ }^{21)}$ 。

\section{3. 朝鮮通信使による鞆浦の風景評価}

朝鮮通信使は，军山を出港し，海路対馬，壱岐，藍島，赤間関， 西津，上関，蒲刈を経て，ほぼ一ヶ月から二ヶ月余り，最む長い 日数で三ヶ月余りの行程で鞆浦に至っている。来訪する時季は一 定ではなく, 四季に及ぶ。鞆浦での滞在は一泊が普通であり, 長 いときでも二泊であった。歴代の通信使の風景記述に基づき, 風 景を見つめる主体と対象景の関係を表一 1 にまとめる。

1607 年第 1 次の慶七松の記述では, 鞆浦に入校する手前で, 海潮山磐台寺（図一 $2^{22}$ 参照）の僧が，海際で御供物を受け取る 様子を船上から眺め, 湘水で屈原 ${ }^{23}$ を祭るときのようだとあらわ され，鞆浦の風景が洞庭湖の風景に見立てられた。1655 年第 6 次の南龍翼は, 紀行文に多くの漢詩を残している。藍島では「遙

表一 1 風景をみつめる主体と対象景の関係

\begin{tabular}{|c|c|c|c|c|c|c|c|c|}
\hline \multicolumn{2}{|c|}{ 歴代通俉使第 1 次回答兼剧逼使 } & \multirow{2}{*}{ 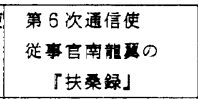 } & \multirow{2}{*}{$\begin{array}{c}\text { 第 } 7 \text { 次通信使 } \\
\text { 訳官金指南の } \\
\text { 「東桎日録」 }\end{array}$} & \multirow{2}{*}{ 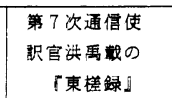 } & \multirow{2}{*}{ 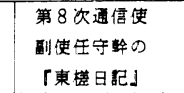 } & \multirow{2}{*}{ 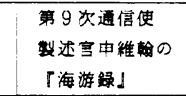 } & \multirow{2}{*}{$\begin{array}{l}\text { 第10次通信使 } \\
\text { 従事官曹命采の } \\
\text { 「㪴使巨本時聞見録」 }\end{array}$} & \multirow{2}{*}{ 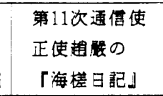 } \\
\hline リアリティ & 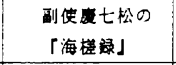 & & & & & & & \\
\hline 釜山出港日 & 1607年2月29日 & 1655年6月9日 & \multicolumn{2}{|c|}{ 1682年 6 月 18 日 } & 1711年7月5日 & 1719年6月20日 & 1748年2 月 12 日 & 1764年10月6日 \\
\hline 滞在日数 & 一泊 & 二泊 & \multicolumn{2}{|c|}{ 一泊 } & 二泊 & 一泊 & 一泊 & 一泊 \\
\hline 風貫距述 & \multicolumn{8}{|c|}{ 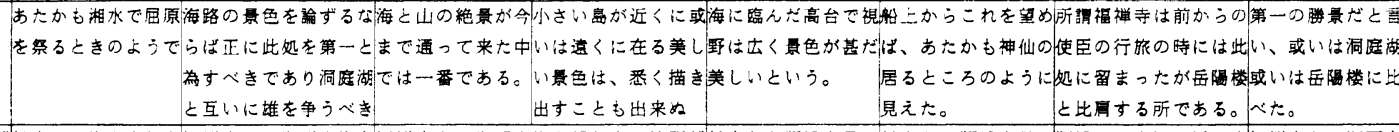 } \\
\hline 䘽界・距離 & 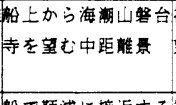 & $\begin{array}{l}\text { 福弾寺から瀬戸内海を } \\
\text { 望む中・息距襍量 }\end{array}$ & \multicolumn{2}{|l|}{ 曼 } & 中距䧼景 & $\begin{array}{l}\text { 万船上から雨浦を見る } \\
\text { 中距離最 }\end{array}$ & 万䊔浦の町を巡る近・中 & $\begin{array}{l}\text { 中福禅寺から瀬戸内 } \\
\text { 海を望む中・遗距 } \\
\text { 帷最 }\end{array}$ \\
\hline 主体の状況 & 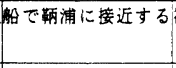 & 福弾寺に滞在する & \multicolumn{2}{|c|}{ 福禅寺に向かう } & \multicolumn{2}{|c|}{$\begin{array}{l}\text { 輌浦に入港するが末蹒浦に入港する } \\
\text { だ下船していない }\end{array}$} & 福掸寺を捂す & 福禅寺に滞在する \\
\hline
\end{tabular}

表 -2 漢詩における風景評価

\begin{tabular}{|c|c|c|c|c|}
\hline テキスト & \multicolumn{2}{|c|}{ 漢詩 } & 铞 & 钼黄上の特徽 \\
\hline 第 6 次通信使 (1655) & 楼如盈結也区共 & 跌鎖高垂断宿嫤 & 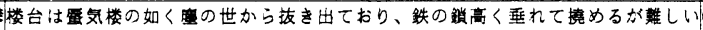 & け镸気楼 =東海の三神山のイメージ \\
\hline 侻毫官南龍理の & 海色秋開甘露寺 & 錘聂夜度落星湾 & 海色活秋に甘露寺に閒かれ、镜の音は夜に落星湾を通って来る & ○「晚鏡」のイメージ \\
\hline 「扶桑録」より & 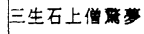 & 萬里㦈頭客破镇 & 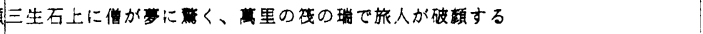 & \\
\hline & 安得羽衣横玉笛 & 岳陧明月箘君山 & 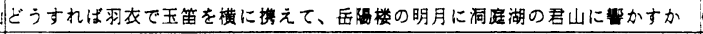 & ○「拾适記」の類型 \\
\hline 第10次通信使 (1748) & 前锌乗槎至 人 & 説此楼 & 先海は册に乗ってきて、それぞれこの楼の莱睛らしさを話し楽しんだ & 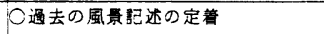 \\
\hline 正使洪辟蛄が福禅寺に & 二海住何所極 & 舆同浮 & 見下ろすと海面ははるか低く見え、老㯕は他の木々ととも浮かんだように見える & S○老樹=古代から繶くイメージ \\
\hline 戉した漠蒔 & 姆只留吾客 & 整群冓 & 空には月が一つ私を客としてもてなしてくれ、町の明かりはつなき止められたた & 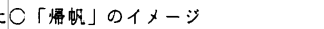 \\
\hline 「朝鲜通信使漢特笨」 & 鳴猶未起 & 英己西流 & くさんの舟をあかあかと昭らす & ○杜甫の「登自陽楼」に次韻した詩 \\
\hline より & & & 夜明けの鐘が鳴っても人々はまだ起き出きず、天の川川はすう西に䫅いている & \\
\hline 第11次通信使 (1754) & 清肖洋月久非徊 & 為是墙楼照得来 & 睛れた月夜に扯をして久しく非䧃する、橙のために斯く照らしてくれるのだ & ○一秋月」のイメージ \\
\hline 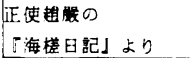 & |干文穓山中海立 & 軅能高築望郷台 & |干文の蚠山が海中に立つ、誰が高い所に望郷台を築くだろうか & $\begin{array}{l}\text { ○海中に迄つ笛山=君山のイメージ } \\
\text { O杜甫の「登高」に次暗した詩 }\end{array}$ \\
\hline
\end{tabular}


かに神仙に従って方丈山を尋ね」年，赤間関では，航路手前の小 倉城の楼閣を望んで「長生不死の薬がもし有るならば正に此の山 中に在るならん」 ${ }^{257}$, 鞆浦では「広いことを比ぶれば正に洞庭湖 之共に論ずるべきで此の山で長生不死の薬を採取できると夢の中 で仙人が私に言ったのだ ${ }^{26)}$ と詠んだ。これらは，除福伝説 ${ }^{27)} の$ イメージが実景に投影されている。また，この年の通信使は，鞆 浦に二泊していて，南龍翼は「終日景色を見物したが，楼の前に 雨が晴れた後の景色が最む清らかで明媢であった」 いる。1682 年第 7 次の金指南之洪禹載はともに，福禅寺から望 む瀬戸内海の風景を絶賛しているが，どちらの記述にも見立ての 表現はなく，対象景の自然地理的ストラクチャ一や風景要素の透 視的輪郭像に対して風景生成を行っている。1711 年第 8 次の任 守幹の記述は，伝え聞いた表現になっている。しかし，この年の 通信使一行は, 州路, 鞆浦で経路で体験した風景について語り合 い, 福禅寺から見る瀬戸内海の風景が日本一だという評価を定着 させた ${ }^{29)}$ 。1719 年第 9 次の申維翰は, 先行研究の考察により ${ }^{2)}$, 鞆浦では「神仙境」の意味づけをもとに風景生成を行った。1748 年第 10 次の時は, 日本側の思惑の違いから，福禅寺ではなく阿 弥陀寺が館舎になった は船に引き返してしまったという ${ }^{31)}$ 。この年の正使洪啓禧は, 福 禅寺をことさらに尋㛊詩を残した。「前輩乗槎至 人々説此楼」 の行は, 第 6 次から数えて五代, 約 110 年の間に鞆浦の風景記述 が定着したことを示している（表一2 参照)。また，洪啓禧は， かつての使館を「対潮楼」と名づけ, 子息の洪景海に書かせた扁 額は，今も福禅寺に残されている（図- 1 参照）。1764 年第 11 次の趙嚴は，「洞庭湖と岳陽楼はまだ見たことがないので」と前 置きし ${ }^{32)}$, 過去の通信使の風景記述を確認するかたちで風景評価 を行っている。

6 次以降の通信使による風景記述においては，以下の基盤的な 風景生成の三つの観点があると考えられる。

a ) 漢詩や山水画から得た洞庭湖や潇湘八景の風景イメージに基 づく見立て

b ）空間の実体的な要件の探索

c ）「日東第一形勝」の定着

a ）の大枠は, 福禅寺を岳陽楼に, 瀬戸内海を洞庭湖に見立る のだが，これに潚湘八景の意味づけが加わる。鲡湘八景のイメー ジは, 宋代の潚湘八景図にあらわされているものでは, 画面全体 が煙霞に包まれ, 大地, 湖面, 空の境界がはっきりしない絵が多 い。第 6 次の南龍翼の漢詩の行「楼如蜃結区買」には, このイメー ジを連想できる (表一 2 参照)。潚湘八景の風景の構成要素には, 落倠（秋に雁が隊列を組みながら飛び来たり飛び去る姿）, 帰帆 (夕刻に船が湊に戻ってくる椂子), 青嵐 (晴れた日の霞や露, あ るいは青葉のころに吹く薰風), 暮雪 (夕暮れ時の雪景色), 秋月
(秋の夜空に讶える満月を望む様子), 夜雨（夜に降るしめやかな 雨の情景), 晚鐘 (寺鐘の鳴り渡る暮れ方の風景), 夕照 (むのが みな茜色に染まる美しい夕映えの風景）がある。これらのどれか が鞆浦の風景の中に見出されることになる。このうち，テキスト で取り上げた中では, 通信使の鞆浦滞在中に夜の雨と雪が降った 、日はなく，雁を見た記述もない。残りの五つはすべて該当する。 寺の鐘の音, 月, 舟は表一 2 の観賞上の特徵で確認できる。「青 嵐」に関しては, 南龍翼が雨上がりの風景を終日観賞して行った 風景生成に類型を求めることができる。b）は, 空間の実体的な 要件に対応して行われた風景生成で, 第 7 次の洪禹載の風景記述 にあるように (表一 1 参照), 鞆浦の海や山などの自然地理的な ストラクチャーや, 建物, 樹木といった構図の中で主に図となる 風景要素の透視的輪郭像が対象景の構成エレメントの中に探索さ れたことである。また，この過程において，風景を見つめる主体 の内面に意味づけられた特定の風景イメージが実景に投影される ことになる。）は，鞆浦の風景が, 経路上の他の風景と比較し た中で最も優れているという評価に一つの形式的な言葉を与える ことで，風景の定着を強く促したということになる。

\section{4．記述を介した風景の定着経緯 \\ (1) 風景の定着経緯}

本研究で考察した通信使のテキストは, 1607 年の第 1 次から 1764 年の第 11 次までの 157 年間, 11 代を数える中 2 次から 5 次 を除く計 7 代の紀行文と漢詩集であった。 2 次から 5 次までの翻 訳文献は入手することができず，本論では考察していないが，第 6 次の『扶桑録』における風景生成への与件となったことは否定 できないと思われる。しかし，『扶桑録』において，鞆浦の風景 評価の枠組みが形成されて以降，11 次に至るまでの約 110 年間 の文献の考察により, 通信使の風景評価の定着が特徵づけられる と考えられる。以下に各代での風景の定着を検証する。

第 1 次の慶七松は, 海潮山磐台寺を見て, 湘水の風景イメージ を鞆浦の風景に最初に導入した。それから約 50 年後, 第 6 次の 南龍翼は，鞆浦の風景を第一だと評価し，洞庭湖の風景イメージ に重ねる記述を残した。次の金指南と洪禹載（第7次）はともに, 自然地理的ストラクチャーに対して風景生成を行い，c）を導き 出している。次の任守幹（第8次）による記述は, 自らの観賞で はなく，伝え聞いた風景評価であり，復路における鞆浦での通信 使間の協議によってc）を定着させている。第 9 次の申維翰は, 過去の評価を認識したうえで，b）に特化している。次の曹命采 （第 10 次）は，福禅寺が対象景構成エレメントから外されそうに なったため，福禅寺から望む瀬戸内海の風景に執着した。同年の 正使洪啓禧の漢詩による風景評価には過去の風景記述の定着や風 景要素の透視的輪郭像もある (表一 2 参照)。したがって，この

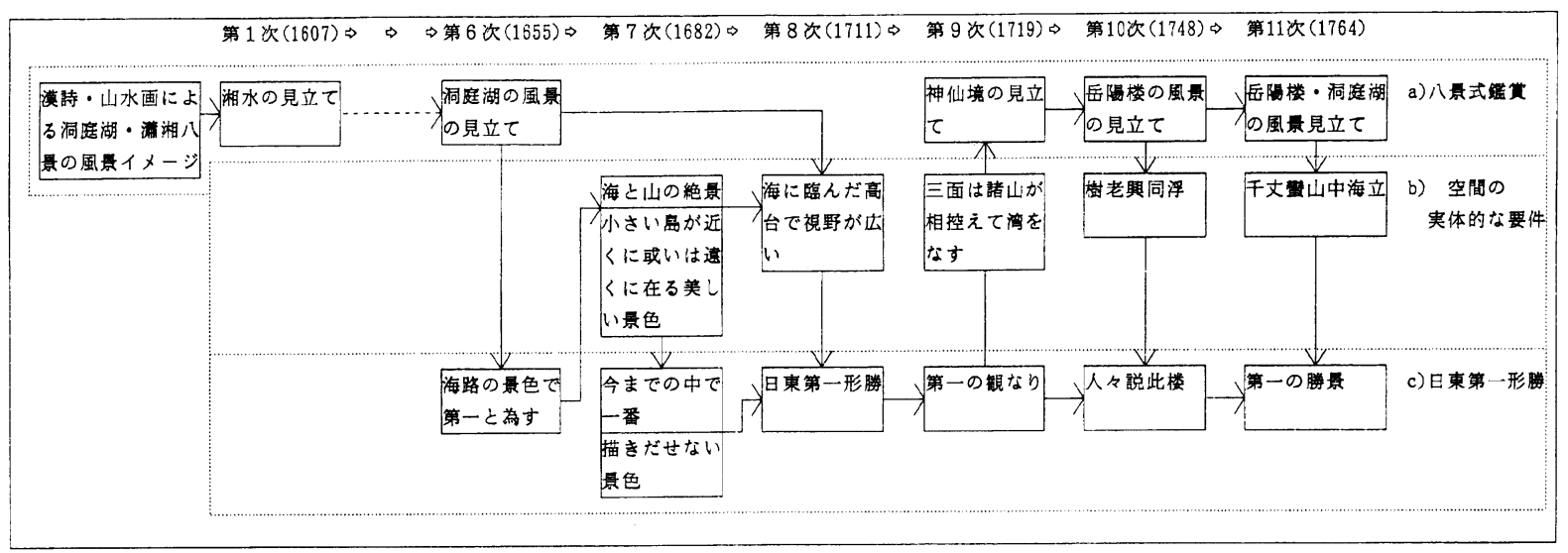

図-3 風景記述の定着経緯 
第 10 次の時点に至って, a), b ), c ) の三つの観点が同時に 風景生成に関わったと考えられる。続く第 11 次の趙嚴の風景記 述には, 表一 1 に見られるようなa）上c）の観点が認められる が，b）の観点からの新たな意味づけはみられない。

図ー3に歴代の通信使の風景記述の定着経緯をフローチャート に示す。

\section{（2）意味づけの図式}

6 次以降の通信使の風景生成における三つの観点は, 過去の通 信使の記述を介して定着した鞆浦の風景の特徵と見なすことがで きそその意味づけの図式には以下の関係が考えられる。

a ）は，b）のために根拠を提供する道具だてになる。b）は， a ）の必要条件を満たす要素を対象景の中に求める作業で, この 過程で, 風景を見つめる主体の内面に空間の実体的な要件が入力 される。これは, 必然的に主体の個性が発揮される工程になる。 洞庭湖や潚湘八景の風景イメージが，東海の三神山に象徴される 除福伝説などの神仙伝から導かれる神仙境のイメージへの拡大や 意味づけの深長化に発展する余地を含むことになる。第 6 次の南 龍翼や第 9 次の申維翰には, この方性が認められる。c）は,

b）によって行われた風景生成が十分条件となってなされる風景 の価値づけである。

これらの観点は，テキストを通じて部分的に次の代の通信使に 引き継がれ，そこでの風景生成の下敷きになる。そして，この風 景生成の循環は，世代を超えて繰り返されたことになる。すなわ ち, この三つの観点は, 各々の通信使による風景生成の中で, 常 に同時にあるのではなくて, その都度の状況に忘じて取り沙汰さ れたことになる。そして，第 10 次の代のときに，福禅寺からの 風景価值が強化されるのに伴い，a），b）， c）の観点が風景観
賞の罒式としてパターン化されたと考えることができる。网式の 内容は，歴代の通信使の風景記述により a ）が風景を見つめる主 体の内面に意味づけられ，それを確かめるためにb）が行われ， 次に鞆浦の空間の実体的な要件により, 風景之対峙する主体は風 景価值を認識し， c ）が定着したということになる。次の第 11 次でもこのパターン化は継承されているが，b）におけるオリジ ナルな発展が見受けられないことも確認できた。

\section{5. 結論}

本研究によって得られた結論は以下の通りである。 1) 歴代の朝鮮通信使による鞆浦での風景記述には, 中国洞庭湖 の風景イメージが最初に下敷きになっており，自然地形風景と人 文風景の兩方に，その意味づけが探し当てられることにより，経 路の中で第一だという評価に繋がった。

2）７次以降の通信使の記述では，鞆浦での過去の風景記述を受 け継ぐために，風景イメージの意味づけを探索したが，それは自 然地理的なストラクチャーや風景要素の透視的輪郭像の認識を深 めることになり，必然的に風景を生成させた。

3 ) 第 9 次の通信使の記述においては, 鞆浦の空間の実体的な要 件の認識が深まると, 当初の洞庭湖や潚湘八景の風景イメージを, その元となる「神仙境」の意味づけまで深長化させて風景生成を 行った。

4) 10 次以降の通信使による風景記述には，第 9 次までの与件 通りに, 洞庭湖・潚湘八景の風景イメージの探索, 空間の実体的 な要件の確認, 風景イメージの実景への投影,「第一形勝」の生 成というパターン化された成式が定着したが，その文面，主体の 内面に㧍けるオリジナルな意味づけは，手薄となった。

\section{注及び引用・参考文献}

1）西田正憲（1999）：瀬戸内海の発見： 中公新書, $44-50$

2 ）西嶋啓一郎・仲間浩一（1999）：江户 時代の朝鮮通信使による風景認識と体 験記述の特徴に関する研究：ランドス ケープ研究 62 (5), 673-676

3 ）慶七松，若松實訳（1997）：海槎録 日朝協会愛知県連合会, $21-37$

4 ）南龍翼・若松實訳（1991）：扶桑録 （上）：日朝協会愛知県連合会，30153

5 ) 金指南・若松實訳 (1990) : 東榚日録: 日朝協会愛知県連合会, $24-44$

6 ）洪禹載・若松實訳 (1989）：東槎録 日朝協会愛知県連合会, $17-47$

7 ) 任守幹・若松實訳 (1993) : 東槎日記 日朝協会愛知県連合会, 26-57

8 ) 申維翰・姜在彦訳 (1974)：海游録 東洋文庫, 18-103

9 ) 曹命采・若松實訳（1993）：奉使日本 時聞見録：日朝協会愛知県連合会, 583

10）趙嚴・若松實訳（1995）：海槎日記 $<$ 日記篇 $>$ : 日朝協会愛知県連合会, $38-131$

趙嚴・若松實訳（1997）：海槎日記
<酬唱録編 > : 日朝協会愛知県連合会, 46

11）鞆の浦歴史民俗史料館編集 : 朝鮮通信 使漢詩集 : 鞆の浦歴史民俗史料館，2345

12）岳陽は，州名では岳州，群名では巴陵 群という。

13）岳州刺史に左遷されていた張説が，開 元四年 (716) に岳州城の西の城門に 楼を築き，南楼と呼んだ。それが後の 岳陽楼である。

14）洞庭山とも呼ばれる。

15）山岳それ自体を神と見なし，また祖霊 や精霊の楼む所として宗教的崇扯を捧 げ，寺院を設けて儀礼を行う信们。

16）伝説中の古代の天子, 舜帝が亡くなっ た之き，舜の二妃，娥皇と女英は，あ とを追って湘汀に身を投げて死んだと 伝えられる。その二人を京ってある墓。

17）秦の始皇帝が前 219 年に, 自信の不老 長寿を山神や地神に祈祷するために行っ たといわれる呪術儀式の印。

18）四川大学古籍整理研究所編（1997） 諸子集成補編十：四川人民出版社, 815

19） 11 世紀後期（北宋の神宗帝の頃）中 国の画家。
20）新藤武弘（1989）：山水画とは何か： 福武書店, 119

21）前掲書 1)，48-49

22）海潮山磐台寺・山陽新聞社編（1996）: 歴史散歩鞆の浦今昔：山陽新聞社，よ り転載。

23）中国戦国時代，楚の国の政治家，名は 平，号は原。懐土・頃襄王に仕え，三 問大夫などを歴任, 謀略に宿り, 放浪 生活をして泪羅水に溺死する。紀元前 343 ? 277?。

24）前掲書 4), 102

25）前掲書 4)，113

26）前掲書 4), 146

27）方土除福が始皇帝の命を受け，東海中 の三神山へ不老長寿の仙薬を採りに出 かけたことが『史記』にしるされてい るが, わが国の伝承では, 除福は日本 に漂着してすみついた，とされている ものがある。

28）前掲書 4), 147

29）前掍書 1 ), 46

30）李進熙（1992）：江戸時代の朝鮮通信 使 : 講談社, 121

31）前掲書 30), 122

32）前掲書 10）<日記篇>, 127

Summary : In order to understand landscaping it is important to understand that there is a projection of image into the reality. In this report the writings of Korean envoys to Japan have been studied; in particular, the similarities they found between Setonaikai Tomonoura and the Chinese landscapes Dohteiko and Shohshoh-Hakkei reported in Chinese poetry. The analysis of these writings revealed similar patterns of thought; namely that the envoys considered Setonaikai Tomonoura to be the most beautiful landscape in Japan because they saw their common image of Dohteiko and Shohshoh-Hakkei reflected in the reality of Setonaikai Tomonoura. 